\title{
The Physiological Effect of Glucagon on Fat-Mobilisation
}

\author{
P. Lefeebvre \\ Institut de Médecine, Département de Clinique et de Pathologie Médicales (Prof. H. Van CAUwEABERGE) \\ Université de Liège -- Belgique \\ Received February 1, 1966
}

Summary. In normal dogs under pentobarbital anaesthesia, intraportal infusion of physiological doses $\{0.002$ $\mu \mathrm{g} / \mathrm{kg} / \mathrm{min}$ ) of cystein-treated glucagon increases markedly the plasma FFA levels in the peripheral blood. This can be considered as an argument for a possible role of glucagon as a physiological regulator of lipid metabolism. lipides.

Effet physiologique du glucagon sur la mobilisation des

Résumé. La perfusion portale de doses physiologiques $(0.002 \mu \mathrm{g} / \mathrm{kg} / \mathrm{min})$ de glucagon traité par la cystéine augmente de façon très significative le taux sanguin des acides gras libres du plasma périphérique. Cette observation constitue un argument en faveur d'un rôle physiologique du glucagon dans le métabolisme des lipides.

Der physiologische Effekt von Glucagon auf die Fettmobilisation.

Zusammenfassung. Die intraportale Infusion von physiologischen Dosen von Glucagon, das mit Cystein behandelt ist $(0.002 \mu \mathrm{g} / \mathrm{kg} / \mathrm{min})$ erhöht bei normalen Hunden unter Pentobarbital-Anaesthesie eindeutig die Plasmaspiegel der freien Fettsäuren im peripheren Blut. Dieser Effekt kann als Hinweis auf die physiologische Bedeutung des Glucagons im Fettstoffwechsel angesehen werden.
In vitro, glucagon increases free fatty acid release from rat adipose tissue (SteINBerg et al., 1959; HAGEN, 1960; WEINGES, 1961). This effect results from increased lipolysis (WEINGES and LöFELER, 1965) with concomitant increased reësterification as shown by VAUGHAN and STEINBERg (1963) with their "non isotopic balance method", and by ourselves (LEFEBVRE, 1966).

An effect on FFA release has been detected by WEINGES (1961) with concentrations of glucagon of $0.004 \mu \mathrm{g} / \mathrm{ml}$ and by LEFHBVRE (1966) with concentrations of $0.002 \mu \mathrm{g} / \mathrm{ml}$, which are in the range of the physiological levels evaluated in plasma by UNGER et al. (1962).

In vivo, the effects of glucagon on plasma FFA have led to conflicting results: a fall in plasma FFA in man was observed by LIPSETT et al. (1960), PENNICK and Hinkue (1960), Eymer et al. (1961) and Dreming et al. (1962), and in dog by SteINBERG et al. (1959); an early rise by WEINGES (1961) in man, and by LEVARLET (1962) in dog; an initial fall and a secondary rise, in man, by FeLBER and van ITALLIE (1958) and by LIPSETT et al. (1960). We recently reported (LEFEBVRE, 1965) that, in man, glucagon at the dose of $1 \mathrm{mg} / \mathrm{m}^{2}$, induces an initial fall of plasma FFA followed by a marked secondary rise, which can be observed between the 2nd and 5th hour after the injection. This initial fall can be reproduced by an hyperglycemia of the same magnitude as the one caused by glucagon, and induced by i.v. glucose infusion. The secondary rise is much more important after glucagon than the small rebound-effect observed after glucose. This secondary rise could correspond to the fat-mobilizing effect of the hormone.

Nevertheless the physiological signification of these experiments has not been established. In the experi- ments reported here, we studied the effects on plasma FFA of physiological doses of glucagon perfused in the physiological site of secretion of the hormone i.e. the portal vein.

\section{Material and Methods}

A short laparotomy was performed in 10 normal mongrel dogs, under sodium pentobarbital anaesthesia. The animals were fasted for 18 hours before the experiment. The body temperature was kept constant by warming blankets. A catheter (Clay Adams P.E. 240) was introduced into the portal vein through the splenic vein. Blood samples were collected from the femoral vein. During the 5 hours of the experiment, $9 \mathrm{ml} /$ hour of normal saline was infused into the portal vein. In 6 out of the 10 animals, a solution of glucagon was substituted for the saline for one hour (cysteintreated glucagon (Novo) in saline at the concentration necessary to give an infusion of $0.002 \mu \mathrm{g} / \mathrm{kg}$ body weight per minute).

Blood glucose was determined according to HoFFMaN's method (1937) adapted to the Technicon AutoAnalyser. FFA were determined by the method of DOLE (1956) modified in our laboratory (LEFEBVRE and Henrioul, 1963).

\section{Results}

Table 1 shows the values of blood glucose and plasma FFA in both the glucagon infused and the control dogs. In the limits of the periods of time studied, we did not observe any difference in blood glucose between the two groups. As regards plasma FFA, the values are significantly higher between the 60th and the 240th minutes in the glucagon-treated animals (Fig. 1). The differences are statistically, highly significant $(p<0.05)$. 
Table 1. Blood glucose and plasma FFA in control and intraportally glucagon-infused dogs

\begin{tabular}{|c|c|c|c|c|c|c|c|c|c|}
\hline & & \multirow{2}{*}{$\begin{array}{l}\text { Initial } \\
\text { values } \\
=100 \%\end{array}$} & \multicolumn{7}{|c|}{$\%$ of initial values (mean of 3 determinations before starting the experiment) } \\
\hline & & & $30 \min$ & $60 \mathrm{~min}$ & 90 min & $120 \min$ & $180 \mathrm{~min}$ & $240 \mathrm{~min}$ & $300 \mathrm{~min}$ \\
\hline \multirow{3}{*}{$\begin{array}{l}0 \\
0 \\
0 \\
0 \\
0 \\
\\
80 \\
\overrightarrow{0} \\
8 \\
0 \\
0\end{array}$} & Control & $\begin{array}{l}76^{1} \pm 2.6^{2} \\
\mathrm{mg} \%\end{array}$ & $97 \pm 3.1$ & $105 \pm 3.1$ & $94 \pm 3.1$ & $96 \pm 3.1$ & $89 \pm 3.1$ & $89 \pm 4.3$ & $87 \pm 7.6$ \\
\hline & $\begin{array}{l}\text { Glucagon } \\
0.002 \mu \mathrm{g} / \\
\mathrm{kg} / \mathrm{min} \\
\text { intra- } \\
\text { portal }^{3}\end{array}$ & $\begin{array}{l}77.8 \neq 4.4 \\
\mathrm{mg} \%\end{array}$ & $101 \pm 4.1$ & $93 \pm 3.2$ & $86 \pm 2.2$ & $82 \pm 3.6$ & $82 \pm 3.9$ & $83 \pm 6.3$ & $86 \pm 7.3$ \\
\hline & $\mathrm{p}$ & N.S. & N.S. & N.S. & N.S. & N.S. & N.S. & N.S. & N.S. \\
\hline \multirow{3}{*}{ 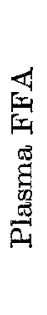 } & Control & $\begin{array}{l}634 \pm 24 \\
\mu \mathrm{Eq} \%\end{array}$ & $84 \pm 8.7$ & $79 \pm 14.1$ & $81 \pm 8.9$ & $90 \pm 7.6$ & $95 \pm 7.6$ & $104 \pm 10.2$ & $110 \pm 12.5$ \\
\hline & $\begin{array}{l}\text { Glucagon } \\
0.002 \mu \mathrm{g} / \\
\mathrm{kg} / \mathrm{min} \\
\text { intra- } \\
\text { portal }^{3}\end{array}$ & $\begin{array}{l}575 \pm 24 \\
\mu \mathrm{Eq} \%\end{array}$ & $116 \pm 11.1$ & $131 \pm 11.4$ & $148 \pm 10.9$ & $156 \pm 12.2$ & $150 \pm 9.4$ & $146 \pm 8.1$ & $148 \pm 9.4$ \\
\hline & $\mathrm{p}$ & N.S. & N.S. & $<0.05$ & $<0.01$ & $<0.01$ & $<0.01$ & $<0.02$ & N.S. \\
\hline & $\begin{array}{l}1 \text { mean. } \\
2 \text { standar } \\
3 \text { during } \\
n \text { of exper } \\
\text { N.S. Not }\end{array}$ & $\begin{array}{l}\text { ror of the } \\
\text { first hour } \\
\text { nts is } 4 \text { i } \\
\text { istically }\end{array}$ & $\begin{array}{l}\text { an. } \\
\text { ificants a }\end{array}$ & in gluce & f & als & & & \\
\hline
\end{tabular}

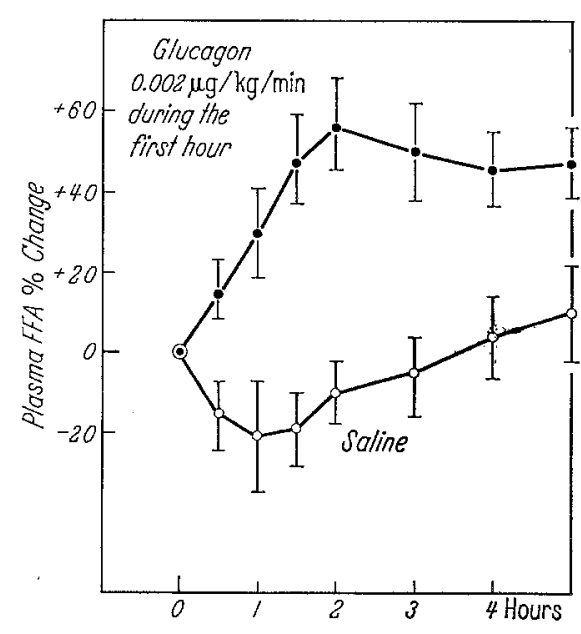

Fig. 1. Changes in plasma FFA during and after intraportal infusion of glucagon. Comparison with saline-infused dogs. Mean of 6 (glueagontreated) and 4 (controls) animals \pm S.F.M.

\section{Discussion}

The dose of $0.002 \mu \mathrm{g} / \mathrm{kg} / \mathrm{min}$ of glucagon infused into the portal vein can be considered as physiological in respect of: (1) the levels of the "glucagonemia" found by UNGER et al. (1962) in the pancreatic venous plasma of chronically hypoglycemic dogs: $680-3100 \mu \mu \mathrm{g}$ $\mathrm{Eq} / \mathrm{ml}$ (mean value $1976 \mu \mu \mathrm{g} \mathrm{Eq} / \mathrm{ml}$ ) and (2) the values of the pancreatic venous blood flow in the dog, which are in the range of $2 \mathrm{ml}$ of blood, approximatively $1 \mathrm{ml}$ of plasma per $\mathrm{kg}$ per min (LovbatrìRes, personal communication).

We have demonstrated that such physiological doses are able to increase the plasma FFA level in peripheral blood. This can be considered as an argument for a possible role of glucagon as a regulator of lipid metabolism.

The lack of hyperglycemic response in our experiments could be explained by: (1) the sensitivity of the hyperglycemic response, which is about $0.1 \mu \mathrm{g} / \mathrm{kg}$ (StaUb and BeHrens, 1954), the total dose given here in 1 hour being $1.2 \mu \mathrm{g} / \mathrm{kg}$ and (2) the fact that we have only studied peripheral blood samples where minimal changes could not be detected but might appear in subhepatic venous blood.

These experiments suggest that the FFA-mobilizing effect of glucagon could be of importance under the physiological conditions that increase its portal concentration, such as fasting or hypoglycemia (UNGER et al., 1962; Unger and EisentraUt, 1965).

We are gratefull to Dr. SCHLICHTKRULL and Dr. JER. sILD, Novo Industri A/S, Copenhagen, for graciously providing us cystein-treated glucagon.

\section{References}

Dotw, V.P.: A relation between non-esterified fatty acids in plasma and the metabolism of glucose. J. clin. Invest. $35,150-154$ (1956).

Dreiltng, D.A., E.L. Bierman, A.F. Debons, P. ElsBACH and I.L. SCHWARTz: Effect of ACTH, hydrocortisone and glucagon on plasma non-esterified fatty acid 
concentration (NEFA) in normal subjects and in patients with liver disease. Metabolism 11, 572-578 (1962).

Eymer, K.P., K. Schwarz and K.F. Weinges: Das Verhalten der veresterten und nichtveresterten Fettsäuren im Serum unter dem Einfluß von Glukagon und Insulin beim Menschen. Klin. Wschr. 39, 631-638 (1961).

Felber, J.P., and J.P. van ItaLitim : Program 40 th Meeting Endocrinol. Soc., p. 50, 1958.

HAGEN, J.H.: Effects of the glucagon on the metabolism of adjpose tissue. J. biol. Chem. 236, 1023-1027 (1961).

HoFFMAN, W.S.: A rapid photoelectric method for the determination of glucose in blood and urine. J. biol. Chem. 120, $51-55(1937)$.

LFFEBVRE, P.: Glucagon et taux sanguin des acides gras non estérifiés chez l'homme. Ann. Endocr. (Paris) 26, $602-608$ (1965).

- Contribution à l'étude du rôle physiologique du glucagon. (En préparation), 1966.

-, and HenriouL, F.: Influence du glucagon sur le taux sanguin et la différence artério-veineuse des acides gras non estérifiés. Ann. Endocr. (Paris) 24, 889-896 (1963).

LevarLet, M.: Action de l'adrénaline et du glucagon sur la glycémie, les lactates et les acides gras du plasma. C. R. Soc. Biol. 156, 1940-1942 (1962).

LipsetT, M.B., H.R. Enget and D.M. Bergenstal: Effects of glucagon on plasma unesterified fatty acids and in nitrogen metabolism. J. Lab. clin. Med. 56, 342$354(1960)$.

Pentck, S.B., and L.E. JR. HinkLe: Depression of food intake induced in healthy subjects by glucagon. New Engl. J. Med. 264, 893-897 (1961).
Staub, A., and O.K. Behrens: The glucagon content of crystalline insulin preparation. J. clin. Invest. 33, $1629-1633$ (1954).

SteinberG, D., E. Shafrir and M. VaughaN: Direct effect of glucagon on release of unesterified fatty acid (UFA) from adipose tissue. Clin. Res. 7, 250 (1959).

UNGER, R.H., and A.M. Eisentraut: Studies of the physiologic role of glucagon. Diabetes, 13, 563-568 (1964).

- A.M. Eisentrauut, M.S. Mc Cadl and L.L. Madison with technical assistance of K.R. Sims and L. PATMAN : Measurements of endogenous glucagon in plasma and the influence of blood glucose upon its secretion. J. clin. Invest. 41, 682-689 (1962).

VAUGHAN, M., and D. STEINBERG: Effect of hormones on lipolysis and esterification of free fatty acids during incubation of adipose tissue "in vitro". J. Lipid Res. 4, $193-199$ (1963).

WeINGEs, K.F.: Der Einfluß von Glukagon und Insulin auf den Stoffwechsel der nicht veresterten Fettsäuren am isolierten Fettgewebe der Ratte in vitro. Klin. Wschr. 39, 293-298 (1961).

-, and G. LÖFFLER: Glucagonempfindliche lipolytische Aktivität im Fettgewebe. Klin. Wschr. 43, 175-176 (1965).

\section{P. Lefebvae}

Inst. de Médecine, Dépt. de Clinique et de Pathologie Médicales

Université de Liège

Liège, Belgique 